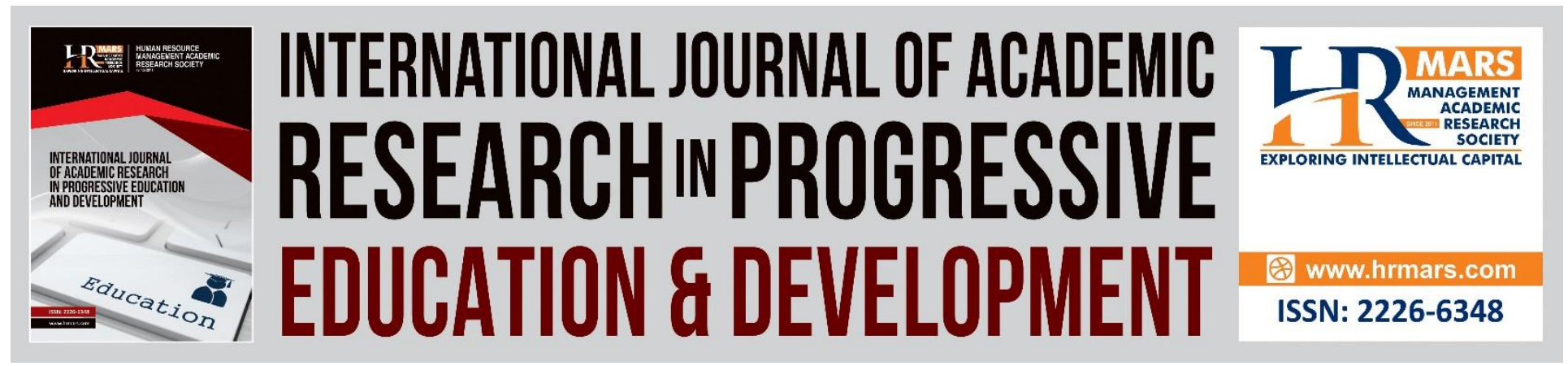

\title{
Industrial Design Graduates' Perspective on E-Learning in Higher Education
}

\author{
Teo Pei Kian, Yusri Kamin, Muhammad Sukri Saud
}

To Link this Article: http://dx.doi.org/10.6007/IJARPED/v9-i2/7965

DOI:10.6007/IJARPED/v9-i2/7965

Received: 11 April 2020, Revised: 02 May 2020, Accepted: 19 June 2020

Published Online: 23 July 2020

In-Text Citation: (Kian, Kamin, \& Saud, 2020)

To Cite this Article: Kian, T. P., Kamin, Y., \& Saud, M. S. (2020). Industrial Design Graduates' Perspective on ELearning in Higher Education. International Journal of Academic Research in Progressive Education \& Development. 9(2), 687-701.

Copyright: (C) 2020 The Author(s)

Published by Human Resource Management Academic Research Society (www.hrmars.com)

This article is published under the Creative Commons Attribution (CC BY 4.0) license. Anyone may reproduce, distribute, translate and create derivative works of this article (for both commercial and non-commercial purposes), subject to full attribution to the original publication and authors. The full terms of this license may be seen at: http://creativecommons.org/licences/by/4.0/legalcode

Vol. 9(2) 2020, Pg. 687 - 701 http://hrmars.com/index.php/pages/detail/IJARPED JOURNAL HOMEPAGE

Full Terms \& Conditions of access and use can be found at http://hrmars.com/index.php/pages/detail/publication-ethics 


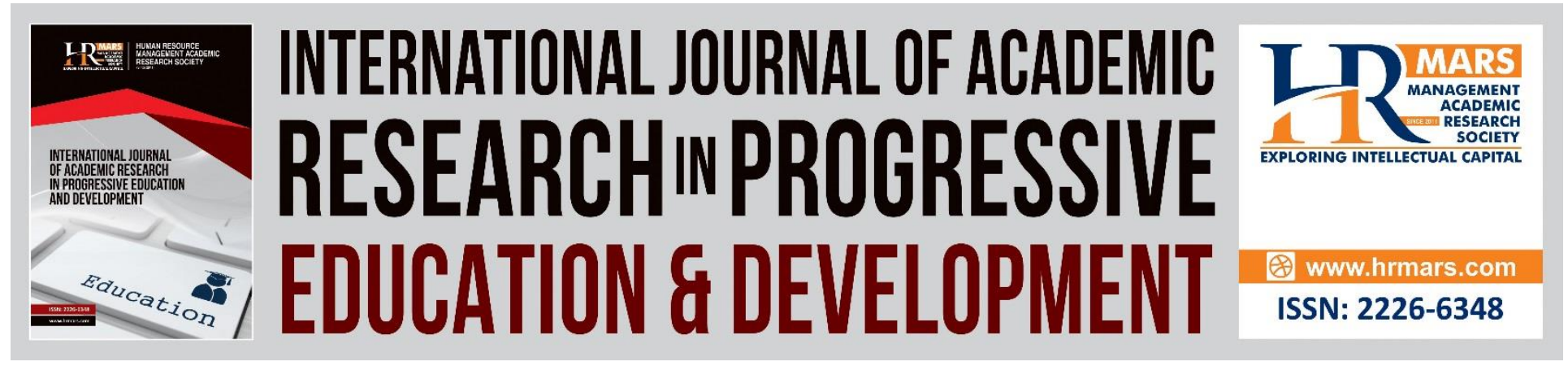

\title{
Industrial Design Graduates' Perspective on E-Learning in Higher Education
}

\author{
Teo Pei Kian \\ Senior Lecturer, Faculty of Art \& Design, Southern University College, Malaysia \\ Yusri Kamin \\ Assoc. Prof., School of Education, Universiti Teknologi Malaysia, Malaysia \\ Muhammad Sukri Saud \\ Professor, School of Education, Universiti Teknologi Malaysia, Malaysia
}

\begin{abstract}
This article discusses the criteria for emphasizing on graduates' perspective on using e-learning in higher education and focus on Industrial Design programme. Nowadays, just theory teaching methods as used in earlier time cannot provide sufficiently well for students' learning especially for design programme like Industrial Design. The use of the Internet, digitalization and virtualization enables the integration of technology and educational resources to help form a learner-oriented teaching environment. This study is seeking to incorporate the platform of creative teaching which is e-learning and including the use of lively transferable skill. The objectives of this article are to study perception of e-learning system as a creative teaching method for Industrial Design programme; to investigate the outcome of e-learning system as a creative teaching method for Industrial Design programme. A quantitative research design was conducted to examine Industrial Design students' perception on e-learning. For the purpose of this study, convenience sampling was employed whereby the population of this study comprised the respondents from Johor Bahru, Malaysia only. A total of 35 Industrial Design students were participated in this study and they were agreed to voluntarily participate in the study. In summary, this article consolidates the effectiveness of e-learning as a type of learning method and the importance of e-learning in higher education for Industrial Design students.
\end{abstract}

Keywords: Industrial Design Education, E-learning, Learning Method, Higher Education, Design Programs

\section{Introduction}

The arrival of innovative and technology-driven teaching era has changed the way of interaction among educators and students (Lou et al., 2012). Nowadays, just theory teaching methods as used in earlier time cannot provide sufficiently well for students' learning especially for design 
programme like Industrial Design. The use of the Internet, digitalization and virtualization enables the integration of technology and educational resources to help form a learner-oriented teaching environment. However, incorporating information and communication technology (ICT) applications into teaching does not assure the enhancement of learning effectiveness. The characteristics and readiness of learners, technology used, curriculum, and network environments must also be considered. (Volman \& Van Eck, 2001)

\section{Background of Research}

The higher education required an intensity of flexibility and adaptability on teaching and learning. Teaching and learning for a new era requires a new model of Industrial Design education because the technology is changing every year (European Union, 2014). It means the Industrial Design education strategy needs a set of teaching methods that influences innovative development, which creates something unique and turns it into knowledge. Therefore, the development of teaching and learning with e-learning on a study environment for creative development is considered a necessary. This research contains criteria for emphasizing on creative teaching method for using e-learning in higher education and focus on design programme. This study is seeking to incorporate the platform of creative teaching which is e-learning and including the use of lively transferable skill.

\section{Objectives}

The objectives of this study are:

1. To study perception of e-learning system as a creative teaching method for Industrial Design programme.

2. To investigate the outcome of e-learning system as a creative teaching method for Industrial Design programme

\section{Research Questions}

1. What is the Industrial Design students' perception of e-learning system as a creative teaching method in higher education?

2. What is the benefit of e-learning for Industrial Design teaching and learning in higher education?

3. What are the challenges of e-learning for creative teaching method in higher education?

\section{Definition of E-learning}

E-learning consider learning that utilize electronic advances to get to instructive educational curriculum outside of a conventional classroom. In most cases, it refers to a course, program or degree delivered completely online ("What is eLearning", 2017). E-learning in education is encourages by the web and its innovation and includes the utilize of the World Wide Web (www) to back instruction and to provide course content (Masrom, 2007). Straight to the point Frank \& Gary (2012) posted a set of definitions outlined to create a more common understanding of elearning. 
Nowadays, e-learning has ended up the essential shape of remove instruction, it is additionally changing education on campus particularly in higher education. Numerous students live on campus for the term of their considers; others live close campus and commute to campus to require classes and to get campus-based bolster administrations. This physical connection has characterized the relationship between the student and the institution. It has moreover made a difference to shape the educational curriculum itself. E-learning has obscured these conventional connections, evacuating geology as a characterizing component within the relationship of student and institution (Sener, 2015)

E-learning is the utilize of innovation to put through lecturers and students who are physically miles apart. There are fundamentally two types of e-learning:

- Synchronous

This type involves interaction of participants with an instructor via the web like virtual classroom. Lecturers and students able to interact through instant messaging, chat, audio and video conferencing. This method has few benefits like lecturers able to log or track learning activities; continuous monitoring and correction; possibilities of global connectivity; and able to personalise the training for each learner.

- Asynchronous

This type allows the participants to complete the WBT (Web-based training) at their own pace, without live interaction with the instructor. Basically, it is information that is accessible on a self-help basis. The speciality of this type is it offers the learners the information they need whenever they need it. The benefit for learner is flexibility of access from anywhere at any time; uniformity of content and one-time cost of production for instructor.

(Cube, 2015)

\section{E-learning for Industrial Design Graduates}

Traditional education especially in the higher education is emphasized on delivering material by way of lecture in classroom, while in a blended learning model lectures can be saved and post online ahead of time so the students can learn on their own time. The classroom time is more feasible to be for structured lessons that emphasize the application of the curriculum to solve problems or work through tasks. Blended learning is a term that using a combination of elearning with traditional classroom methods and independent study to create a new methodology (Mindflash, 2019). In a blended learning context, instructors resolve learning objectives, assign learning tasks, interact with students, give feedback, and evaluate students' achievement (Alshwiah, 2009).

Many researches stated that e-learning is important for lecturers and students in higher education (Songkram, 2014). The higher instruction change that happened more than a decade which centered on learners by utilizing innovation to bolster the teaching and learning process and need to create around higher arrange considering (National Education Act B.E, 1999). Thus, when Industrial Design student enters the learning in higher education institutions, it is necessary to further development and focus on creativity. According to Innovative Learning Technologies 
(2009), e-learning is developing well known in design industry and design education, with preparing programmes in office and IT instruments topping the list.

Niki (2012) pointed that the effective e-learning environments ought to consider not as it were data and information transmission, but also social and dialogical intelligent between lecturers and students. Subsequently, the design environment in higher education decides the sorts of social intelligent that can encourage teaching and learning in design education. According to the University of Freiburg (2014), e-learning in higher education allows visualization of complex collection of facts through multimedia presentations or simulation processes, Industrial Design lecturers and students able to support construction of design knowledge and competence through communicative and collaborative projects.

\section{Methodology}

A quantitative research design was conducted to examine Industrial Design students' perception on e-learning. For the purpose of this study, convenience sampling was employed whereby the population of this study comprised the respondents from Johor Bahru, Malaysia only. A total of 35 Industrial Design students were participated in this study and they were agreed to voluntarily participate in the study. They were required to complete a survey questionnaire and return it upon completion.

A set of survey questionnaire which consisted 15 questions and four sections: Section A Personal Information; Section B - Rationale of E-learning; Section C - The Benefits of E-learning and Section D - The Obstacles of E-learning were distributed to the students. The first section focused on the demographic details of the respondents. Section B of this study was used to answer the first research question while sections $C$ and $D$ were used to address the second and third research questions respectively. The data analysis was done by using SPSS Version 22, as to determine the descriptive statistics. The frequency, percentage and mean of the items were reported in Results Section.

\section{Results}

The results were presented in four sections according to the questionnaire.

\section{Section A}

Table 1: Gender of the respondents

\begin{tabular}{|l|l|l|l|l|l|}
\hline \multicolumn{2}{|c|}{} & Frequency & Percent & $\begin{array}{l}\text { Valid } \\
\text { Percent }\end{array}$ & $\begin{array}{l}\text { Cumulative } \\
\text { Percent }\end{array}$ \\
\hline \multirow{3}{*}{ Valid } & Male & 11 & 31.4 & 31.4 & 31.4 \\
\cline { 2 - 6 } & Female & 24 & 68.6 & 68.6 & 100.0 \\
\cline { 2 - 6 } & Total & 35 & 100.0 & 100.0 & \\
\hline
\end{tabular}

Table 1 shows the gender of the respondents. A total of 35 respondents which consisted of 11 male respondents (31.4\%) and 24 female respondents (68.6\%) were involved in this study. 
INTERNATIONAL JOURNAL OF ACADEMIC RESEARCH IN PROGRESSIVE EDUCATION AND DEVELOPMENT

Vol. 9, No. 2, 2020, E-ISSN: $2226-6348$ @ 2020 HRMARS

Table 2: Age of the respondents

\begin{tabular}{|l|l|l|l|l|l|}
\hline \multicolumn{2}{|c|}{} & Frequency & Percent & $\begin{array}{l}\text { Valid } \\
\text { Percent }\end{array}$ & $\begin{array}{l}\text { Cumulative } \\
\text { Percent }\end{array}$ \\
\hline \multirow{4}{*}{ Valid } & $18-20$ & 20 & 57.0 & 57.0 & 57.0 \\
\cline { 2 - 6 } & $21-22$ & 15 & 43.0 & 43.0 & 100.0 \\
\cline { 2 - 6 } & & & & & \\
\cline { 2 - 6 } & & & & & \\
\cline { 2 - 6 } & & & & & \\
\cline { 2 - 6 } & Total & 35 & 100.0 & 100.0 & \\
\hline
\end{tabular}

The age of respondents is shown in Table 2. The age of respondents was classified into five categories and the respondents' age was ranged from 18-22 years old. There were 20 respondents (57\%) in the range of $18-20$ years old; followed by 15 respondents from $21-22$ years old (43\%).

Table 3: Year of study

\begin{tabular}{|l|l|l|l|l|l|}
\hline \multicolumn{2}{|c|}{} & Frequency & Percent & $\begin{array}{l}\text { Valid } \\
\text { Percent }\end{array}$ & $\begin{array}{l}\text { Cumulative } \\
\text { Percent }\end{array}$ \\
\hline \multirow{3}{*}{ Valid } & 1 & 30 & 86.0 & 86.0 & 86.0 \\
\cline { 2 - 6 } & 2 & 5 & 14.0 & 14.0 & 100.0 \\
\cline { 2 - 6 } & Total & 35 & 100.0 & 100.0 & \\
\hline
\end{tabular}

There were $86 \%$ of the respondents were in their first year of study while the remaining $14 \%$ of the respondents were in their second year of study.

\section{Section B}

Table 4: Definition of e-learning

\begin{tabular}{|c|c|c|c|c|}
\hline & Options & Frequency & Percentage & Mean \\
\hline Distance learning & $\begin{array}{l}\text { No } \\
\text { Yes }\end{array}$ & $\begin{array}{l}20 \\
15\end{array}$ & $\begin{array}{l}57.1 \\
42.9\end{array}$ & 1.4286 \\
\hline Online course/ learning & $\begin{array}{l}\text { No } \\
\text { Yes } \\
\end{array}$ & $\begin{array}{l}8 \\
27 \\
\end{array}$ & $\begin{array}{l}22.9 \\
77.1 \\
\end{array}$ & 1.7714 \\
\hline Web-based learning & $\begin{array}{l}\text { No } \\
\text { Yes }\end{array}$ & $\begin{array}{l}16 \\
19\end{array}$ & $\begin{array}{l}45.7 \\
54.3\end{array}$ & 1.5429 \\
\hline Web-based training & $\begin{array}{l}\text { No } \\
\text { Yes } \\
\end{array}$ & $\begin{array}{l}27 \\
8 \\
\end{array}$ & \begin{tabular}{|l|}
77.1 \\
22.9 \\
\end{tabular} & 1.2286 \\
\hline All learning environments & $\begin{array}{l}\text { No } \\
\text { Yes } \\
\end{array}$ & $\begin{array}{l}29 \\
6 \\
\end{array}$ & \begin{tabular}{|l|}
82.9 \\
17.1 \\
\end{tabular} & 1.1714 \\
\hline $\begin{array}{l}\text { Learning on your own at your } \\
\text { own pace }\end{array}$ & $\begin{array}{l}\text { No } \\
\text { Yes } \\
\end{array}$ & $\begin{array}{l}19 \\
16 \\
\end{array}$ & $\begin{array}{l}54.3 \\
45.7 \\
\end{array}$ & 1.4571 \\
\hline Have no idea & $\begin{array}{l}\text { No } \\
\text { Yes }\end{array}$ & $\begin{array}{l}33 \\
2 \\
\end{array}$ & $\begin{array}{l}94.3 \\
5.7 \\
\end{array}$ & 1.0571 \\
\hline
\end{tabular}


Vol. 9, No. 2, 2020, E-ISSN: $2226-6348$ @ 2020 HRMARS

Table 4 shows the definition of e-learning which understood by the respondents. The respondents could choose more than one meaning which they believed to be true for the term e-learning. It can be noticed that majority of the respondents understood that e-learning can be used for online course/ learning (77.1\%) and web-based learning (54.3\%). However, there were also 2 respondents did not know what e-learning was referred to.

Table 5: Time spent on e-learning

\begin{tabular}{|l|l|l|l|l|l|}
\hline \multicolumn{2}{|c|}{} & Frequency & Percent & $\begin{array}{l}\text { Valid } \\
\text { Percent }\end{array}$ & \multirow{2}{*}{ Mean } \\
\hline \multirow{4}{*}{ Valid } & 0 hours per week & 6 & 17.1 & 17.1 & \\
\cline { 2 - 5 } & $1-3$ hours per week & 18 & 51.4 & 51.4 & \\
\cline { 2 - 5 } & 4-6 hours per week & 5 & 14.3 & 14.3 & \multirow{3}{*}{2.4000} \\
\cline { 2 - 5 } & $7-9$ hours per week & 5 & 14.3 & 14.3 & \\
\cline { 2 - 5 } & $\begin{array}{l}\text { more than 15 hours per } \\
\text { week }\end{array}$ & 1 & 2.9 & 2.9 & \\
\cline { 2 - 6 } & Total & 35 & 100.0 & 100.0 & \\
\hline
\end{tabular}

Based on the results shown in table 5, more than half (51.4\%) of the respondents spent 1-3 hours of time on e-learning per week.

Table 6: Purposes of using e-learning

\begin{tabular}{|c|c|c|c|c|}
\hline & Options & Frequency & $\begin{array}{l}\text { Percentag } \\
\text { e }\end{array}$ & Mean \\
\hline For submitting assignments & $\begin{array}{l}\text { No } \\
\text { Yes }\end{array}$ & $\begin{array}{l}3 \\
32 \\
\end{array}$ & $\begin{array}{l}8.6 \\
91.4 \\
\end{array}$ & 1.9143 \\
\hline $\begin{array}{l}\text { For interacting with other } \\
\text { students: }\end{array}$ & $\begin{array}{l}\text { No } \\
\text { Yes } \\
\end{array}$ & $\begin{array}{l}29 \\
6 \\
\end{array}$ & \begin{tabular}{|l|}
82.9 \\
17.1 \\
\end{tabular} & 1.1714 \\
\hline $\begin{array}{l}\text { To engage and participating in } \\
\text { discussion forums }\end{array}$ & $\begin{array}{l}\text { No } \\
\text { Yes }\end{array}$ & $\begin{array}{l}19 \\
16\end{array}$ & $\begin{array}{l}54.3 \\
45.7\end{array}$ & 1.4571 \\
\hline $\begin{array}{l}\text { To check announcements } \\
\text { posted by the lecturers }\end{array}$ & $\begin{array}{l}\text { No } \\
\text { Yes } \\
\end{array}$ & $\begin{array}{l}13 \\
22 \\
\end{array}$ & $\begin{array}{l}37.1 \\
62.9 \\
\end{array}$ & 1.6286 \\
\hline To access study resources & $\begin{array}{l}\text { No } \\
\text { Yes }\end{array}$ & $\begin{array}{l}12 \\
23\end{array}$ & $\begin{array}{l}34.3 \\
65.7\end{array}$ & 1.6571 \\
\hline
\end{tabular}

The next question of the survey questionnaire is related to students' purposes of using e-learning, as shown in Table 6 . The respondents used e-learning for variety purposes such as to submit assignments (91.4\%), to check announcements posted by the lecturers or tutors $(62.9 \%)$ and to access study resources (65.7\%). 
INTERNATIONAL JOURNAL OF ACADEMIC RESEARCH IN PROGRESSIVE EDUCATION AND DEVELOPMENT

Vol. 9, No. 2, 2020, E-ISSN: 2226-6348 @ 2020 HRMARS

Table 7: Perception on live lectures over internet

\begin{tabular}{|l|l|l|l|l|}
\hline & Options & Frequency & Percentage & Mean \\
\hline $\begin{array}{l}\text { Do you believe you can have live } \\
\text { lectures over the internet, as in } \\
\text { done in the classroom? }\end{array}$ & No & 25 & 71.4 & \multirow{2}{*}{10} \\
\hline
\end{tabular}

Table 7 shows the students' perception on live lectures over internet. Most of the students (25 out of 35 respondents) believed on the item while 10 respondents still doubt on the applicability of having live lectures.

Table 8: Immediate feedback on questions

\begin{tabular}{|c|c|c|c|c|}
\hline & Options & Frequency & Percentage & Mean \\
\hline $\begin{array}{l}\text { Do you know you can ask } \\
\text { questions and get immediate } \\
\text { feedback when studying in e- } \\
\text { learning, just as is done in the } \\
\text { classroom? }\end{array}$ & $\begin{array}{l}\text { Yes } \\
\text { No }\end{array}$ & $\begin{array}{l}23 \\
12\end{array}$ & \begin{tabular}{|l}
65.7 \\
34.3
\end{tabular} & 1.3429 \\
\hline
\end{tabular}

Results in Table 8 indicates that the students understand that by using e-learning, they can get immediate feedback on the questions asked, just like in the normal classroom. A total of 23 respondents chose option yes while the remaining 12 respondents chose option no.

Table 9: Respondents' perception on e-learning

\begin{tabular}{|c|c|c|c|c|}
\hline & Options & Frequency & Percentage & Mean \\
\hline $\begin{array}{l}\text { I can foresee the usefulness } \\
\text { of e-learning }\end{array}$ & $\begin{array}{l}\text { Strongly Agree } \\
\text { Agree } \\
\text { Disagree } \\
\text { Strongly } \\
\text { Disagree }\end{array}$ & $\begin{array}{l}9 \\
22 \\
4 \\
0\end{array}$ & $\begin{array}{l}25.7 \\
62.9 \\
11.4 \\
0\end{array}$ & 1.8571 \\
\hline $\begin{array}{l}\text { Studying through e-learning } \\
\text { can increase my learning } \\
\text { effectively, as I will have } \\
\text { easy access to learning } \\
\text { materials. }\end{array}$ & $\begin{array}{l}\text { Strongly Agree } \\
\text { Agree } \\
\text { Disagree } \\
\text { Strongly } \\
\text { Disagree } \\
\end{array}$ & $\begin{array}{l}5 \\
26 \\
4 \\
0\end{array}$ & $\begin{array}{l}14.3 \\
74.3 \\
11.4 \\
0\end{array}$ & 1.9714 \\
\hline $\begin{array}{l}\text { Learning electronically can } \\
\text { improve my course } \\
\text { performance as I will not } \\
\text { need to travel to campus, } \\
\text { but study at the comfort of } \\
\text { my home }\end{array}$ & $\begin{array}{l}\text { Strongly Agree } \\
\text { Agree } \\
\text { Disagree } \\
\text { Strongly } \\
\text { Disagree }\end{array}$ & $\begin{array}{l}7 \\
22 \\
5 \\
1\end{array}$ & $\begin{array}{l}20.0 \\
62.9 \\
14.3 \\
2.9\end{array}$ & 2.0000 \\
\hline
\end{tabular}


INTERNATIONAL JOURNAL OF ACADEMIC RESEARCH IN PROGRESSIVE EDUCATION AND DEVELOPMENT

Vol. 9, No. 2, 2020, E-ISSN: 2226-6348 @ 2020 HRMARS

\begin{tabular}{|c|c|c|c|c|}
\hline $\begin{array}{l}\text { Using e-learning system can } \\
\text { enable me to accomplish } \\
\text { task more quickly, since I } \\
\text { will move at own pace. }\end{array}$ & $\begin{array}{l}\text { Strongly Agree } \\
\text { Agree } \\
\text { Disagree } \\
\text { Strongly } \\
\text { Disagree }\end{array}$ & $\begin{array}{l}12 \\
19 \\
4 \\
0\end{array}$ & $\begin{array}{l}34.3 \\
54.3 \\
11.4 \\
0\end{array}$ & 1.7714 \\
\hline $\begin{array}{l}\text { believe e-learning } \\
\text { platforms are user friendly. }\end{array}$ & $\begin{array}{l}\text { Strongly Agree } \\
\text { Agree } \\
\text { Disagree } \\
\text { Strongly } \\
\text { Disagree }\end{array}$ & $\begin{array}{l}9 \\
21 \\
5 \\
0\end{array}$ & $\begin{array}{l}25.7 \\
60.0 \\
14.3 \\
0\end{array}$ & 1.8857 \\
\hline $\begin{array}{l}\text { It is easy for me to find } \\
\text { necessary information } \\
\text { when using an e-learning } \\
\text { platform. }\end{array}$ & $\begin{array}{l}\text { Strongly Agree } \\
\text { Agree } \\
\text { Disagree } \\
\text { Strongly } \\
\text { Disagree } \\
\end{array}$ & $\begin{array}{l}10 \\
21 \\
4 \\
0\end{array}$ & $\begin{array}{l}28.6 \\
60.0 \\
11.4 \\
0\end{array}$ & 1.8286 \\
\hline $\begin{array}{l}\text { think e-learning is an } \\
\text { innovative concept and } \\
\text { must be encouraged. }\end{array}$ & $\begin{array}{l}\text { Strongly Agree } \\
\text { Agree } \\
\text { Disagree } \\
\text { Strongly } \\
\text { Disagree } \\
\end{array}$ & $\begin{array}{l}11 \\
19 \\
5 \\
0\end{array}$ & $\begin{array}{l}31.4 \\
54.3 \\
14.3 \\
0\end{array}$ & 1.8286 \\
\hline $\begin{array}{l}\text { I think e-learning platform } \\
\text { will be fun to use. }\end{array}$ & $\begin{array}{l}\text { Strongly Agree } \\
\text { Agree } \\
\text { Disagree } \\
\text { Strongly } \\
\text { Disagree } \\
\end{array}$ & $\begin{array}{l}11 \\
22 \\
2 \\
0\end{array}$ & $\begin{array}{l}31.4 \\
62.9 \\
5.7 \\
0\end{array}$ & 1.7429 \\
\hline $\begin{array}{l}\text { I will use e-learning in the } \\
\text { future for studies. }\end{array}$ & $\begin{array}{l}\text { Strongly Agree } \\
\text { Agree } \\
\text { Disagree } \\
\text { Strongly } \\
\text { Disagree }\end{array}$ & $\begin{array}{l}8 \\
26 \\
1 \\
0\end{array}$ & $\begin{array}{l}22.9 \\
74.3 \\
2.9 \\
0\end{array}$ & 1.8000 \\
\hline
\end{tabular}

Item 9 requires the students to show the degree of agreement on the statements which applies to the respondents the most. Majority of the respondents showed their agreement (included both strongly agree and agree) on all the statements mentioned in Table 9 and the mean of all the statements above were equal or less than 2.000 which gave a meaning of the results were skewed to agreement. 
INTERNATIONAL JOURNAL OF ACADEMIC RESEARCH IN PROGRESSIVE EDUCATION AND DEVELOPMENT

Vol. 9, No. 2, 2020, E-ISSN: $2226-6348$ @ 2020 HRMARS

\section{Section C}

Table 10: Respondents' perception on off-campus support

\begin{tabular}{|l|l|l|l|l|}
\hline & Options & Frequency & Percentage & Mean \\
\hline $\begin{array}{l}\text { Do you get support when you } \\
\text { are off-campus in terms of }\end{array}$ & Yes & 23 & 65.7 & \\
accessing resources? & No & 12 & 34.3 & 1.3429 \\
\hline
\end{tabular}

23 respondents stated that they received off-campus support when they faced difficulty in accessing the resources from e-learning while 12 respondents did not receive support when they were off-campus.

Table 11: Respondents' perception technology

\begin{tabular}{|l|l|l|l|l|}
\hline & Options & Frequency & Percentage & Mean \\
\hline $\begin{array}{l}\text { Has the technology enabled you } \\
\text { to access study resources } \\
\text { effectively? }\end{array}$ & Yes & 26 & 74.3 & 1.2571 \\
\hline
\end{tabular}

According to table 11 , the students (74.3\%) perceived that technology can help them to access study resources effectively.

Table 12: Benefits of using e-learning for learning

\begin{tabular}{|l|l|l|l|l|}
\hline & Options & Frequency & $\begin{array}{l}\text { Percentag } \\
\text { e }\end{array}$ & Mean \\
\hline Ease of access to information: & $\begin{array}{l}\text { No } \\
\text { Yes }\end{array}$ & $\begin{array}{l}5 \\
30\end{array}$ & $\begin{array}{l}14.3 \\
85.7\end{array}$ & 1.8571 \\
\hline $\begin{array}{l}\text { Easy to get supervision } \\
\text { wherever you are }\end{array}$ & $\begin{array}{l}\text { No } \\
\text { Yes }\end{array}$ & $\begin{array}{l}27 \\
8\end{array}$ & $\begin{array}{l}77.1 \\
22.9\end{array}$ & 1.2286 \\
\hline $\begin{array}{l}\text { Safe digital environment for } \\
\text { students to submit work }\end{array}$ & $\begin{array}{l}\text { No } \\
\text { Yes }\end{array}$ & $\begin{array}{l}16 \\
19\end{array}$ & $\begin{array}{l}45.7 \\
54.3\end{array}$ & 1.5429 \\
\hline $\begin{array}{l}\text { Combining of both synchronous } \\
\text { and asynchronous learning }\end{array}$ & $\begin{array}{l}\text { No } \\
\text { Yes }\end{array}$ & $\begin{array}{l}25 \\
10\end{array}$ & $\begin{array}{l}71.4 \\
28.6\end{array}$ & 1.2857 \\
\hline Potential for re-use of content: & $\begin{array}{l}\text { No } \\
\text { Yes }\end{array}$ & $\begin{array}{l}23 \\
12\end{array}$ & $\begin{array}{l}65.7 \\
34.3\end{array}$ & 1.3429 \\
\hline $\begin{array}{l}\text { Students can learn at their own } \\
\text { pace }\end{array}$ & $\begin{array}{l}\text { No } \\
\text { Yes }\end{array}$ & $\begin{array}{l}12 \\
23\end{array}$ & $\begin{array}{l}34.3 \\
65.7\end{array}$ & 1.6571 \\
\hline $\begin{array}{l}\text { Facilitates the management of } \\
\text { student records }\end{array}$ & $\begin{array}{l}\text { No } \\
\text { Yes }\end{array}$ & $\begin{array}{l}17 \\
18\end{array}$ & $\begin{array}{l}48.6 \\
51.4\end{array}$ & 1.5143 \\
\hline
\end{tabular}

Table 12 shows the results obtained from the respondents regarding the benefits that they can receive when they are using e-learning. Among the 7 statements, the respondents believed that by using e-learning, they can access to information easily $(85.7 \%)$, can have safe digital environment $(54.3 \%)$, can learn at their own pace $(65.7 \%)$ and it can facilitate the management of student records (51.4\%). However, only a minority of students believed that e-learning can help them get supervision easily (22.9\%), can have both synchronous and asynchronous learning (28.6\%) and can re-use of content (34.3\%). 
INTERNATIONAL JOURNAL OF ACADEMIC RESEARCH IN PROGRESSIVE EDUCATION AND DEVELOPMENT

Vol. 9, No. 2, 2020, E-ISSN: $2226-6348$ @ 2020 HRMARS

Table 13: Respondents' perception on the benefits of using e learning as a student

\begin{tabular}{|c|c|c|c|c|}
\hline & Options & $\begin{array}{l}\text { Frequenc } \\
\mathrm{y}\end{array}$ & $\begin{array}{l}\text { Percenta } \\
\text { ge }\end{array}$ & Mean \\
\hline Flexibility in time and place. & $\begin{array}{l}\text { Strongly Agree } \\
\text { Agree } \\
\text { Disagree } \\
\text { Strongly } \\
\text { Disagree }\end{array}$ & $\begin{array}{l}12 \\
21 \\
2 \\
0\end{array}$ & $\begin{array}{l}34.3 \\
60.0 \\
5.7 \\
0\end{array}$ & 1.7143 \\
\hline $\begin{array}{l}\text { Ease and quick share of } \\
\text { educational material. }\end{array}$ & \begin{tabular}{|l|} 
Strongly Agree \\
Agree \\
Disagree \\
Strongly \\
Disagree \\
\end{tabular} & $\begin{array}{l}9 \\
20 \\
6 \\
0\end{array}$ & $\begin{array}{l}25.7 \\
57.1 \\
17.1 \\
0\end{array}$ & 1.9143 \\
\hline $\begin{array}{l}\text { Improved collaboration and } \\
\text { interactivity among students. }\end{array}$ & $\begin{array}{l}\text { Strongly Agree } \\
\text { Agree } \\
\text { Disagree } \\
\text { Strongly } \\
\text { Disagree } \\
\end{array}$ & $\begin{array}{l}8 \\
23 \\
3 \\
1\end{array}$ & $\begin{array}{l}22.9 \\
65.7 \\
8.6 \\
2.9\end{array}$ & 1.9143 \\
\hline $\begin{array}{l}\text { Access to higher education for all } \\
\text { applicants. }\end{array}$ & $\begin{array}{l}\text { Strongly Agree } \\
\text { Agree } \\
\text { Disagree } \\
\text { Strongly } \\
\text { Disagree }\end{array}$ & $\begin{array}{l}9 \\
19 \\
7 \\
0\end{array}$ & $\begin{array}{l}25.7 \\
54.3 \\
20.0 \\
0\end{array}$ & 1.9429 \\
\hline $\begin{array}{l}\text { Possibility of working with e- } \\
\text { learning. In your perception }\end{array}$ & \begin{tabular}{|l|} 
Strongly Agree \\
Agree \\
Disagree \\
Strongly \\
Disagree \\
\end{tabular} & $\begin{array}{l}7 \\
21 \\
7 \\
0\end{array}$ & $\begin{array}{l}20.0 \\
60.0 \\
20.0 \\
0\end{array}$ & 2.0000 \\
\hline $\begin{array}{l}\text { Accommodates different types of } \\
\text { learning styles }\end{array}$ & \begin{tabular}{|l} 
Strongly Agree \\
Agree \\
Disagree \\
Strongly \\
Disagree \\
\end{tabular} & $\begin{array}{l}6 \\
23 \\
6 \\
0\end{array}$ & $\begin{array}{l}17.1 \\
65.7 \\
17.1 \\
0\end{array}$ & 2.0000 \\
\hline Quick feedback. & $\begin{array}{l}\text { Strongly Agree } \\
\text { Agree } \\
\text { Disagree } \\
\text { Strongly } \\
\text { Disagree }\end{array}$ & $\begin{array}{l}7 \\
12 \\
14 \\
2\end{array}$ & $\begin{array}{l}20.0 \\
34.3 \\
40.0 \\
5.7\end{array}$ & 2.3143 \\
\hline $\begin{array}{l}\text { Wide and diverse interactions. In } \\
\text { your perception, please rate the } \\
\text { benefits of e-learning to you as a } \\
\text { student. }\end{array}$ & $\begin{array}{l}\text { Strongly Agree } \\
\text { Agree } \\
\text { Disagree } \\
\text { Strongly } \\
\text { Disagree }\end{array}$ & $\begin{array}{l}4 \\
26 \\
4 \\
1\end{array}$ & $\begin{array}{l}11.4 \\
74.3 \\
11.4 \\
2.9\end{array}$ & 2.0571 \\
\hline
\end{tabular}


Vol. 9, No. 2, 2020, E-ISSN: $2226-6348$ @ 2020 HRMARS

\begin{tabular}{|l|l|l|l|l|}
\hline $\begin{array}{l}\text { Updated learning material. In } \\
\text { your perception, please rate the } \\
\text { benefits of e-learning to you as a } \\
\text { student. }\end{array}$ & $\begin{array}{l}\text { Agree } \\
\text { Disagree } \\
\text { Strongly } \\
\text { Disagree }\end{array}$ & $\begin{array}{l}5 \\
5\end{array}$ & $\begin{array}{l}14.3 \\
71.4\end{array}$ & \multirow{2}{*}{2.0000} \\
\hline $\begin{array}{l}\text { Assist in learning. In your } \\
\text { perception, please rate the }\end{array}$ & $\begin{array}{l}\text { Strongly Agree } \\
\text { Agree }\end{array}$ & 7 & 20.0 & \\
$\begin{array}{l}\text { benefits of e-learning to you as a } \\
\text { student. }\end{array}$ & $\begin{array}{l}\text { Disagree } \\
\text { Strongly } \\
\text { Disagree }\end{array}$ & 5 & 65.7 & 1.9429 \\
\hline
\end{tabular}

For all the statement above, more students showed their agreement (strongly agree and agree option) than disagreement (disagree and strongly disagree option).

\section{Section D}

Table 14: Challenges of using e-learning

\begin{tabular}{|c|c|c|c|c|}
\hline & Options & Frequency & $\begin{array}{l}\text { Percentag } \\
\text { e }\end{array}$ & Mean \\
\hline Having no access to computers. & $\begin{array}{l}\text { No } \\
\text { Yes }\end{array}$ & $\begin{array}{l}15 \\
20\end{array}$ & $\begin{array}{l}42.9 \\
57.1\end{array}$ & 1.5714 \\
\hline No electricity & \begin{tabular}{|l} 
No \\
Yes \\
\end{tabular} & \begin{tabular}{|l|}
23 \\
12 \\
\end{tabular} & $\begin{array}{l}65.7 \\
34.3 \\
\end{array}$ & 1.3429 \\
\hline Low level of English competency. & $\begin{array}{l}\text { No } \\
\text { Yes }\end{array}$ & $\begin{array}{l}22 \\
13 \\
\end{array}$ & $\begin{array}{l}62.9 \\
37.1 \\
\end{array}$ & 1.3714 \\
\hline Need for face to face interaction. & \begin{tabular}{|l|} 
No \\
Yes \\
\end{tabular} & $\begin{array}{l}19 \\
16 \\
\end{array}$ & $\begin{array}{l}54.3 \\
45.7 \\
\end{array}$ & 1.4571 \\
\hline Low level of awareness. & \begin{tabular}{|l} 
No \\
Yes \\
\end{tabular} & $\begin{array}{l}23 \\
12 \\
\end{array}$ & $\begin{array}{l}65.7 \\
34.3 \\
\end{array}$ & 1.3429 \\
\hline Not familiar with the systems. & $\begin{array}{l}\text { No } \\
\text { Yes }\end{array}$ & $\begin{array}{l}21 \\
14\end{array}$ & $\begin{array}{l}60.0 \\
40.0\end{array}$ & 1.4000 \\
\hline Lack of technical support. & $\begin{array}{l}\text { No } \\
\text { Yes }\end{array}$ & $\begin{array}{l}20 \\
15\end{array}$ & $\begin{array}{l}57.1 \\
42.9\end{array}$ & 1.4286 \\
\hline
\end{tabular}

Table 14 shows the challenges encounter by the respondents while they are using e-learning. It can be noticed that the students did not faced many problems when they were experiencing elearning as more of the students chose option 'no' than option 'yes'. The only challenges which faced by most of the respondents was that they did not have access to computers.

\section{Discussion and Conclusion}

This section is showing the summary of the findings that based on the objectives of the research. Based from the results, the objectives of research are fulfilled.

The Industrial Design students believed that e-learning was a type of learning method which was carried out online. However, the students were not keen of using e-learning though they understand that they can use e-learning for variety of purposes. E-learning can be used to support 
traditional lecture method and it can promote collaborative learning among students. It promotes interaction among the students (Razali \& Yahya, 2010) and the students can cooperate with each other regardless of the environments because it can be used anytime at any place. Yet, many respondents still confused the function of e-learning as they perceived that interaction with others through e-learning is impossible and as well as they cannot engage in discussion forums in e-learning.

As to replace the traditional learning method and to enhance the effectiveness of Industrial Design students' learning, live lectures should be a creative way of teaching the students whereby the students can study at a place which they are comfortable at. They do not need to stay in a classroom as to attend a two- or three-hours lecture, but they can study at home and receive the same quality of knowledge that they can gained when they attend the class. It can help the students to improve their learning and they can finish their task more quickly. Abdillah (2013) stated that e-learning help to transform traditional learning method to a faceless learning method. To make e-learning more effective to be used, it should include also the function of having live lectures so that it fulfils the needs of students who required face-to-face interaction. Technology can help the Industrial Design students to learn effectively. The use of e-learning enables the students to get to access the design resources easily and the students can get any updated design issues online. The appropriate learning method should not be only focused on printed materials but also the online resources. The lecturers can use e-learning to share resources with the students and the students can help each other through e-learning platform. It brings a lot of benefits to the students as it eases the process of accessing information and the students are responsible to own learning.

In conclusion, e-learning is an effective way of teaching which tally with the aims of $21^{\text {st }}$ century learning method. It is a student-centred learning method and it encourages the students to work with each other to solve the problem. The use of e-learning should not be focus only on the submission of assignments, but the lecturers should be more alert on the different useful functions that can improve students' learning and performance. The traditional learning is never enough to help the Industrial Design students to acquire enough knowledge and practical skills to solve the problems that they may face in real-life situation, but the use of technology can help to facilitate the process of learning.

\section{Acknowledgement}

The authors would like to thank the support from two universities: Southern University College, Malaysia and Universiti Teknologi Malaysia.

\section{Corresponding Author}

Teo Pei Kian, Faculty of Art \& Design, Southern University College, Malaysia

Email: pkteo@sc.edu.my 
INTERNATIONAL JOURNAL OF ACADEMIC RESEARCH IN PROGRESSIVE EDUCATION AND

DEVELOPMENT

Vol. 9, No. 2, 2020, E-ISSN: $2226-6348$ @ 2020 HRMARS

\section{References}

Abdillah, L. A. (2013). Students Learning Center Strategy Based on E-learning and Blogs. Prosiding SNST ke-4 Tahun 2013.

Afshari, M., Bakar, K. A., Luan, W. S., Smah, B. A., \& Fooi, F. S. (2009). Factors Affecting Teachers's Use of Information. International Journal of Instruction, 2 (1), 77-104.

Alain, F. (2001). Rethinking Design Education for the $21^{\text {st }}$ Century: Theoretical, Methodological, and Ethical Discussion. MIT Press, 17 (1), 5-17.

Ali, G. (2013). The Role of ICT to Make Teaching-Learning Effective in Higher Institutions of Learning in Uganda. International Journal of Innovative Research in Science, Engineering and Technology. 2 (8), 4061-4073.

Brent, C. M. (2014). Understanding, Teaching and Nurturing Creativity: Who Is Going To Do It? Creative Studies Graduate Student Master's Projects. Paper 203.

Buzzetto-More, N. A. (2008). Student Perceptions of Various E-learning Components. Interdisciplinary Journal of E-learning and Learning Objects, 4, 113-135.

Christensen, T. (2015). The Differences Between Imagination, Creativity, and Innovation. Retrieved 3 December 2019, from https://creativesomething.net/post/119280813066/the differences-between-imagination-creativity

Cube, G. (2015). Different Types of E-learning and What Suits Me Best. Retrieved from http://www.gc-solutions.net/resources/articles/different-types=of-e-learning-andwhat-suits-me-best.html access on 3 December 2019.

Dron, J., Anderson, T., \& Siemens, G. (2011). Putting Things in Context: Designing Social Media for Education. Proceedings of the European Conference on e-learning;2011, 178.

Instruction, D. (2014). Reference Table: e-Learning Types and Approaches. T\&L Stocklate, AY2014.

Education Scotland. (2013). Creativity Across Learning 3-18. Retrieved from https://dera.ioe.ac.uk/18518/7/Creativity3to18_tcm4-814361_Redacted.pdf access on 12 August 2017.

Hao, J., \& Tang, M. X. (2010). Web-Based Learning Platforms Integrating Social Networking for Design Education at High Schools in China. Computational Intelligence and Software Engineering (CiSE). China: IEEE Xplore.

Işıl, O. I., \& Zeynep K. (2019). Industrial Design Education in the Age of Digital Products. The Design Journal, 22 (1), 1973-1982, DOI: 10.1080/14606925.2019.1594922

International Education Advisory Board. (2008). Learning in the 21 $1^{\text {st }}$ Century: Teaching Today's Students on Their Terms. Retrieved from https://www.certiport.com/Portal/Common/DocumentLibrary/IEAB_Whitepaper040808.p df. access on 13 July 2015.

Janette, R. H., Liyan S., \& Richard, E. W. (2009). Social Learning Theory and Web-Based Learning Environment. A Review of Research and Discussion of Implications, American Journal of Distance Education.

Kolko, J. (2005). New Techniques in Industrial Design Education. $6^{\text {th }}$ International Conference of the European Academy of Design Proceedings. Germany: The European Academy of Design. 2005. 
Lim, B. (2015). A Discussion on Creativity and Design Education in Singapore and Malaysia. Journal of Research in Humanities and Social Science, 3(2), 56-61.

Linda, N. (2014). What is Creativity? Creativity at Work. Retrieved from https://www.creativityatwork.com/2014/06/24/creativity-education-matters/ access on 15 August 2018.

Lou, S. J., Chen, N. C., Tsai, H. Y., Tseng, K. H., \& Shih, R. C. (2012). Using blended creative teaching: Improving a teacher education course on designing materials for young children. Australasian Journal of Educational Technology, 28(5), 776- 792.

Mary, M. (2014). New Modes of Learning and Teaching in Higher Education. Luxembourg: Publications Office of the European Union.

Mihaela, E. R., \& C. Cole. (2008). Enabling Creative Thinking in Digital Design Education. Retrieved from http://docplayer.net/16991301-Enabling-creative-thinking-in-digital-designeducation.html access on 5 August 2018.

Niki, L. (2012). Supporting Social Awareness in Collaborative E-learning. British Journal of Educational Technology. https://doi.org/10.1111/j.1467-8535.2011.01184.x.

OECD. (2016). Innovating Education and Educating for Innovation. Retrieved from http://www.oecd.org/education/ceri/GEIS2016-Background-document.pdf access on 15 July 2019.

OECD. (2018). The Future of Education and Skills. Retrieved from https://www.oecd.org/education/2030/E2030\%20Position\%20Paper\%20(05.04.2018).pdf access on 20 July 2019.

Razali, N. S. M., \& Yahya, N. (2010). Blended Learning: Overcome the Weaknesses of E-learning and Traditional Approach. Edupress 2010.

Ruby, S. (2015). How to Apply Social Learning Theory for Effective E-Learning. Retrieved from https://www.pulselearning.com/blog/how-to-apply-social-learning-theory-for-effectiveelearning/ access on 10 August 2018.

Sener, J. (2015). E-learning Definitions. Retrieved from https://onlinelearningconsortium.org/updated-e-learning-definitions-2/ access on 5 December 2017.

Sisko, J. (2014). Social Media's Role in Product Design and Development. Retrieved from https://carabinercomms.com/social-media/social-medias-role-in-product-design-anddevelopment/ access on 5 December 2019.

Songkram, N. (2015). E-learning system in virtual learning environment to develop creative thinking for learners in higher education. Procedia-Social and Behavioral Sciences, 174, 674679.

Vassiliou, A. (2014). New Modes of Learning and Teaching in Higher Education. Luxembourg: Publications Office of the European Union.

Volman \& Van. (2001). Gender equity and information technology in education: The second decade. Review of Educational Research, 71(4), 613-634. 